\title{
RISK FACTORS, ETIOLOGIC SUBTYPES, AND PROGNOSIS OF PATIENTS WITH RECURRENT ISCHEMIC STROKE
}

\author{
Ülker ANADOL KELLECI*, Ayşe Destina YALÇIN*, Zakir SAKCI** \\ *University of Health Sciences Umraniye Educational and Research Hospital, \\ Neurology Clinic, İstanbul, TURKEY \\ **University of Health Sciences Umraniye Educational and Research Hospital, \\ Radiology Clinic, İstanbul, TURKEY
}

\begin{abstract}
INTRODUCTION: In this study, stroke etiology, risk factors and post-stroke short-term prognosis of patients with recurrent ischemic stroke (RIS) were compared in terms of their gender.

METHODS: A comprehensive assessment of medical records of 18 patients who were hospitalized in the Neurology Clinic of Umraniye Education and Research Hospital of Health Sciences University, due to RIS between January 2011 and January 2017 was performed. Demographic characteristics, risk factors, stroke severity in the first 24 hours, stroke etiology and short-term disabilities were compared in terms of gender. The stroke severity was determined by the National Institutes of Health Stroke Scale (NIHSS) and short-term disability was determined by using the Rankin Disability Scale (mRS) on the 7th day after stroke. 'Trial of ORG 10172 in Acute Stroke Treatment' (TOAST) classification was used for the etiology of ischemic stroke. RESULTS: Five patients with RIS (28\%) were female and thirteen patients with RIS (72\%) were male. Hypertension was the common risk factor in both genders (78\%). No statistically significant difference was found between genders in terms of risk factors and short-term disability ( $p>0.05)$. Cardioembolic stroke was common subtype in female patients whereas largeartery atherosclerosis (LAA) stroke was common subtype in male patients $(p<0.05)$.

DISCUSSION and CONCLUSION: This study showed that RIS is more common for male than female. Most patients with RIS had more than one risk factor. This suggested that optimal control of vascular risk factors after the first stroke might have an important role in secondary prevention of ischemic stroke.
\end{abstract}

Keywords: Stroke, recurrence, risk factors, prognosis.

\section{REKÜRREN İSKEMIK İNMELİ HASTALARDA RİSK FAKTÖRLERİ, İNME ETIYOLOJiSİ VE PROGNOZ}

\section{ÖZET}

GİRIŞ̧ ve AMAÇ: Bu çalışmada rekürren iskemik inme geçiren hastaların her iki cinsiyette inme etiyolojisi, inme risk faktörleri ve inme sonrası kısa döneme ait prognozları açısından karşılaştırılmaları amaçlanmıştır.

YÖNTEM ve GEREÇLER: Çalışma Ocak 2011-Ocak 2017 tarihleri arasında Sağllk Bilimleri Üniversitesi Ümraniye Eğitim ve Araștırma Hastanesi Nöroloji kliniğinde rekürren iskemik inme (RIS) nedeniyle yatan 18 hastanın dosya bilgileri incelenerek yürütülmüștür. Hastaların demografik özellikleri, risk faktörleri, ilk 24 saat içindeki inme şiddetleri, inme etiyolojileri ve kısa döneme ait özürlülükleri kaydedilmiş ve cinsiyet açısından birbirleriyle kıyaslanmıştır. İnme şiddeti 'The National Institutes of Health Stroke Scale' (NIHSS) ile, kısa döneme ait özürlülük ise inme sonrası 7. günde Rankin özürlülük ölçeği (mRS) kullanılarak belirlenmiștir. İskemik inme etiyolojisi için 'Trial of ORG 10172 in Acute stroke Treatment' (TOAST) sınıflaması kullanilmiștır.

BULGULAR: RIS'li hastaların beşi (\%28) kadın, onüçü (\%72) erkekti. Her iki cinsiyette hipertansiyon en sık (\%78) görülen risk faktörü idi. Risk faktörleri ve kısa döneme ait özürlülük açısından her iki cinsiyet arasında istatistiksel farklılık saptanmadı ( $p>0.05)$. İskemik inme alt tipi olarak kadınlarda kardiyoembolik, erkeklerde geniş arter aterosklerozuna (LAA) bağlı inmenin daha sık olduğu görüldü $(\mathrm{p}<0.05)$.

Corresponding author: Ülker Anadol Kelleci, MD. University of Health Sciences Umraniye Educational and Research Hospital, Neurology Clinic, İstanbul, TURKEY

Telephone: +902166321818 E-mail: uanadol@hotmail.com

Received: 03.01.2019 Accepted: 09.07.2019

This article should be cited as following: Anadol Kelleci Ü, Yalçın A.D, Sakcı Z. Risk factors, etiologic subtypes, and prognosis of patients with recurrent ischemic stroke. Turkish Journal of Cerebrovascular Diseases 2019; 25 (2): 101-105. doi: 10.5505/tbdhd.2019.19484 
TARTIŞMA ve SONUÇ: Çalışma RIS’nin erkeklerde kadınlara göre daha sık görüldüğünü göstermiştir. Çalışma ayrıca RIS’li hastaların çoğunun birden fazla risk faktörüne sahip olduğunu göstermiștir. Bu da vasküler risk faktörlerinin ilk inmeden sonra etkin bir şeklide düzenlenmesinin inme tekrar oranlarını azaltmada önemli bir role sahip olabileceğine işaret etmektedir.

Anahtar Sözcükler İnme, rekürren, risk faktörleri, prognoz.

\section{INTRODUCTION}

Stroke is a sudden, vascular-originated clinical syndrome with neurological symptoms and findings due to focal cerebral dysfunction. A recurrent stroke is a newly developed cerebrovascular event after the previous stroke (1). As with all types of cerebrovascular diseases, ischemic stroke has the highest risk of recurrence in the first year and such risk gradually decreases over time $(2,3)$. The risk of recurrent ischemic stroke (RIS) within five years following first episode is reported between $15-40 \%(4,5)$. The first year following the initial stroke, the risk of RIS is higher (between 6-14\%) than the risk in subsequent years (4\% annually) (5-7). The recurrent stroke incidence is maximum in the first 30 days after initial stroke (8).

While a significant reduction in ischemic stroke recurrence rates were achieved with the use of antithrombotic agents, the problem underlying RIS still remains unclear. Studies indicate that vascular risk factors are associated with both stroke recurrence and mortality in the post-stroke period $(9,10)$.

Most of the vascular risk factors are modifiable. Systematic evaluation of risk factors, stroke etiology and antithrombotic drugs used prior to recurrent stroke may be helpful in reducing the risk of stroke recurrence. In this study, the stroke etiology, the risk factors of stroke and the post-stroke short term prognosis in patients with RIS were compared in terms of gender.

\section{MATERIAL AND METHODS}

The study was carried out on the patients over the age of 18 years who were hospitalized due to RIS in the Neurology clinic of Health Sciences University Ümraniye Education and Research Hospital between January 2011 and January 2017. Ischemic stroke diagnosis was made as a result of neurological deficit exceeding 24 hours consistent with infarcts demonstrated by computerized brain tomography or magnetic resonance imaging. Hypertension, diabetes mellitus, hyperlipidemia, coronary artery disease, peripheral artery disease and smoking were identified as risk factors for ischemic stroke. Smoking was defined as smoking one cigarette per day. Diabetes mellitus, hypertension, coronary and peripheral artery disease were included, if diagnosed by the physician at any time before stroke. The severity of stroke within the first 24 hours of acute stroke was assessed using 'The National Institutes of Health Stroke Scale' (NIHSS), and the short-term disability was measured using the Modified Rankin Scale (mRS) on the 7th day after stroke. Electrocardiography, holter monitorization for 24 Hours, carotid-vertebral artery Doppler ultrasound, transesophageal echocardiography, transthoracic echocardiography, cranial MR angiography (MRA) examinations of the patients were evaluated and the leukoaraiosis detected in imaging studies was noted. 'Trial of ORG 10172 in Acute stroke Treatment' (TOAST) classification was preferred for the etiological classification of ischemic stroke (Stroke associated with large arterial atherosclerosis (LAA), cardioembolic stroke, stroke due to small vessel disease, other and unknown) (11). Information on patients' previous stroke was obtained by reviewing previous files, and the antithrombotic drugs used after the first stroke were recorded. Ischemic stroke etiology, risk factors, severity of stroke at first day, and mRS results in the 7 th day of stroke were compared with each other for both genders.

The study was approved by the local ethics committee.

Descriptive statistics such as mean, standard deviation, minimum, median and maximum were used to define continuous variables. Two independent variables which do not have a normal distribution were compared using the MannWhitney $U$ test. Comparisons of categorical variables were made with Chi-square test (Fisher Exact test where appropriate). Correlation between two continuous variables divergent from normal distribution was investigated with the 
Spearman Correlation Coefficient. The statistical significance level was determined to be at level 0.05 . Analyses were performed by using the MedCalc Statistical Software version 12.7.7 (MedCalc Software bvba, Ostend, Belgium; http://www.medcalc.org; 2013) Program.

\section{RESULTS}

The study was conducted on 18 patients admitted to the Neurology Clinic of Umraniye Education and Research Hospital of Health Sciences University due to ischemic stroke recurrence. $28 \%$ of the patients $(n=5)$ were female and $72 \%(n=13)$ were male. The age ranged from 36 to 89 years, with an average age of 72 years. 8 patients ( $45 \%)$ out of 18 were treated with antiplatelet ( 6 patients with acetyl salicylic acid, 2 patients with clopidogrel), 4 patients (22 $\%$ ) with anticoagulants (2 patients with warfarin, 1 patient with rivaroxaban, 1 patient with dabigatran), 6 patients (33\%) were not using antithrombotic therapy. The demographic characteristics of the RIS patient group are shown in Table I.

Table I. Demographic characteristics of men and women.

\begin{tabular}{lll}
\hline & $\mathrm{n}(\%)$ & Median age (yrs) \\
\hline Male & $13(72.2)$ & 72 \\
Female & $5(27.8)$ & 73.6 \\
Total & $18(100)$ & 72.5 \\
\hline
\end{tabular}

Risk factors and etiology: The most common risk factor for patients with RIS was hypertension (78 $\%$ ), followed by smoking (39\%), diabetes mellitus (28\%), coronary artery disease (17 \%), hyperlipidemia (6\%), and peripheral arterial disease (6\%). Table II shows the comparison of the risk factors of 18 patients with RIS between genders.

The etiology of RIS was LAA (50\%) and cardioembolism (50 \%). Table III shows the distribution of stroke etiology in both genders.

Atrial fibrillation was the cause in 6 of 8 patients with cardioembolic stroke, patent foramen ovale was the cause in 1 patient and akinetic segment detected in transthoracic echocardiography was the cause in 1 patient.

The non-stenotic intracranial atherosclerotic changes on MRA were found in 4 patients (22\%).
Table II. Risk factors according to gender.

\begin{tabular}{|c|c|c|c|}
\hline $\mathrm{N}(\%)$ & Female & Male & $\mathrm{P}^{1}$ \\
\hline Hypertension & & & 1.00 \\
\hline None & $1(25)$ & $3(75)$ & \\
\hline Yes & $4(28.6)$ & $10(71.4)$ & \\
\hline Diabetes Mellitus & & & 0.583 \\
\hline None & $3(23.1)$ & $10(76.9)$ & \\
\hline Yes & $2(40)$ & $3(60)$ & \\
\hline Hyperlipidemia & & & 0.278 \\
\hline None & $4(23.5)$ & $13(76.5)$ & \\
\hline Yes & $1(100)$ & 0 & \\
\hline Coronary Heart Disease & & & 1.00 \\
\hline None & $4(26.7)$ & $11(73.3)$ & \\
\hline Yes & $1(33.3)$ & $2(66.7)$ & \\
\hline Smoking & & & 0.101 \\
\hline None & $5(45.5)$ & $6(54.5)$ & \\
\hline Yes & 0 & $7(100)$ & \\
\hline Peripheral arterial disease & & & 0.278 \\
\hline None & $4(23.5)$ & $13(76.5)$ & \\
\hline Yes & $1(100)$ & 0 & \\
\hline
\end{tabular}

1Fisher Exact Test

Table III. TOAST according to gender.

\begin{tabular}{|c|c|c|c|}
\hline $\mathrm{N}(\%)$ & Female & Male & $\mathrm{P}^{1}$ \\
\hline TOAST & & & 0.029 \\
\hline Large artery atherosclerosis & 0 & $9(100)$ & \\
\hline Cardioembolic & $5(55.6)$ & $4(44.4)$ & \\
\hline
\end{tabular}

These 4 patients had also simultaneous extracranial carotid artery disease.

The median NIHSS for the participants of the study was $3.7+2.2$, and NIHSS scores did not differ between genders $(\mathrm{p}=0.296)$.

Median value of the mRS scores in patients at the 7 th day was $2.5+1.3$, and the mRS values did not differ between genders $(\mathrm{p}=0.335)$. LAA had a severe disability rate of $11 \%$, while the cardioembolic group had $16 \%$. No correlation was found between the number of risk factors and the initial stroke severity $(p=0.665) .72 \%$ of the patients had leukoaraiosis and there was no statistically significant difference between the genders in terms of the presence of leukoaraiosis $(\mathrm{P}=1.00)$

Time interval between two strokes: The time interval between the two ischemic strokes in the study ranged from 0.5 to 26 months, and ischemic stroke recurrence occurred in the first 12 months in $15(85 \%)$ of the patients. The average time interval between two ischemic strokes was 7.9 \pm 7.8 months (Figure). 


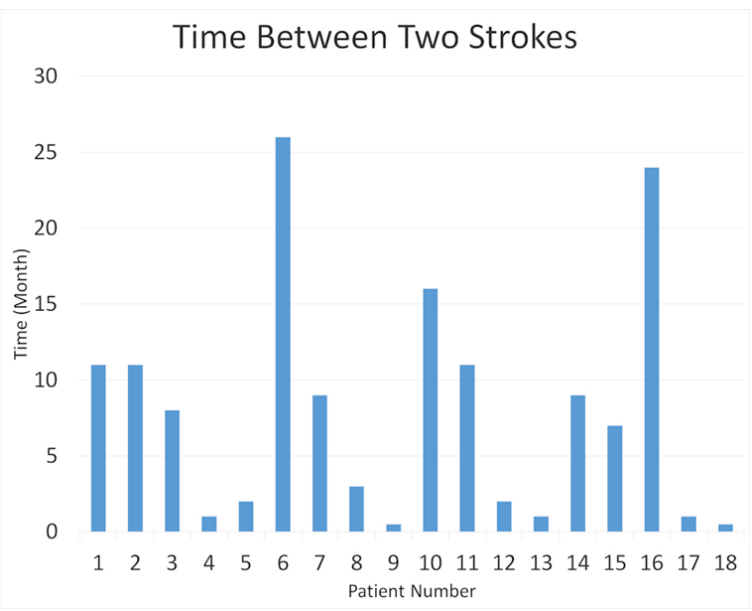

Figure. The time interval between two strokes of 18 patients with RIS.

\section{DISCUSSION}

Prevention of cerebrovascular diseases is crucial as they cause disability and take place among the most common causes of death after heart disease. In this study, vascular risk factors, stroke etiology, current use of antithrombotic drugs, and short-term stroke prognosis were compared for both genders in patients with RIS in order to shed light on the prevention of stroke recurrences.

In this study, the majority of patients with RIS were male $(72 \%)$. All patients except one patient had multiple risk factors, and hypertension was the most common risk factor. Although there was no statistically significant difference between the genders in terms of risk factors, it was observed that hypertension, diabetes, coronary artery disease and smoking were more frequent in male patients. For this reason, it was suggested that the cause of stroke recurrence being more common in males is due to the higher number of risk factors in this group.

Studies indicate that female gender is more susceptible to cardioembolic stroke than other stroke subtypes, and males tend to suffer from LAA or small vessel disease (12-15). In this study, it was also seen that cardioembolic stroke was more frequent in female patients and strokes due to LAA were more frequent in male patients with RIS but this difference did not reach statistical significance.

It was observed that $67 \%$ of patients with RIS were using regular antiplatelet or anticoagulant therapy. This suggests that the risk factors could be determinants of stroke recurrence.
The presence of leukoaraiosis on brain MRI of a high proportion of patients as high as $72 \%$ suggests that leukoaraiosis is a risk of ischemic stroke recurrence, however this should be supported by comparative studies.

The severe disability rate in LAA-related strokes was $11 \%$, this was $16 \%$ in the cardioembolic group, suggesting that TOAST groups may provide a limited prediction of recurrent stroke in terms of morbidity.

The fact that $83 \%$ of the patients had a stroke recurrence within 1 year after the first episode indicates that the treatment of risk factors should not be delayed.

Although intracranial atherosclerotic changes were detected in 4 patients (22\%), it was not directly associated with RIS due to the absence of stenosis of $50 \%$ or more in the symptomatic arteries. However, these results suggest that even without severe stenosis, intracranial atherosclerotic disease may have a role in stroke recurrence.

There were some limitations for this study, such as the small number of patients, the lack of data collection to assess the longer-term prognosis after recurrent stroke, obesity and physical inactivity as a risk factor not included in the evaluation and control of risk factors in the period after the first stroke cannot be evaluated. Another limitation of the study was the inability to perform recurrent Holter monitoring to detect paroxysmal atrial fibrillation.

In conclusion, this study suggests that patients with RIS have a higher number of risk factors, especially hypertension, and RIS is more common in males. Therefore, in order to achieve optimal secondary prevention of patients with ischemic stroke, detection and appropriate treatment of vascular risk factors as well as antithrombotic therapy are important.

\section{REFERENCES}

1. Modrego PJ, Pina MA, Mar Fraj M, et al. Type, causes, and prognosis of stroke recurrence in the province of Teruel, Spain. A Five-year Analysis. Neurol Sci 2000; 21: 355- 360.

2. Leoo T, Lindgren A, Petersson J, et al. Risk factors and treatment at recurrent stroke onset. Results from the recurrent stroke quality and epidemiology (RESQUE) study. Cerebrovasc Dis 2008; 25: 254-260.

3. Boysen G, Truelsen T. Prevention of recurrent stroke. J Neurol Sci 2000; 21: 67-72.

4. Hardie K, Jamrozik K, Hankey GJ, et al. Trends in Five-Year Survival and Risk of Recurrent Stroke after First-Ever Stroke in the Perth Community Stroke Study. Cerebrovasc Dis. 2005; 19: 179-185. 
5. Burn J, Dennis M, Bamford J, et al. LongTerm Risk of Recurrent Stroke after a First-Ever Stroke. The Oxfordshire Community Stroke Project. Stroke 1994; 25: 333-337.

6. De la Camara AG, Arche JFV, Vivas PF, et al. Recurrence after a First- ever Ischemic Stroke: Development of a Clinical Prediction Rule. Research in Neurology: An International Journal.2013; 2013: 13.

7. Dhamoon MS, Sciacca RR, Rundek T, et al. Recurrent stroke and cardiac risks after first ischemic stroke: the Northern Manhattan Study. Neurology. 2006; 66: 641-646.

8. State of the Nation. Stroke Statistics - January, 2016.

9. Naess H. Cerebral infarction in young adults. Tidsskr Nor Laegeforen 2007;127:751-3.

10. Naess H, Waje-Andreassen U, Nyland H. Risk factor burden predicts long-term mortality in young patients with arterial cerebral infarction. Acta Neurol Scand 2013; 127: 92-6.
11. Adams Jr HP, Bendixen BH, Kappelle L, et al. Marsh EE 3rd. Classification of subtype of acute ischemic stroke. Stroke 1993; 24: 35-41.

12. Förster A, Gass A, Kern R, et al. Gender differences in acute ischemic stroke:etiology, stroke patterns and response to thrombolysis. Stroke 2009; 40: 2428-2432.

13. Yesilot NF, Koyuncu BA, Coban O, et al. Gender differences in acute stroke:Istanbul medical school stroke registry. Neurol India 2011; 59: 174-179.

14. Smith MA, Lisabeth LD, Brown DL, et al. Gender comparisons of diagnostic evaluation for ischemic stroke patients. Neurology 2005; 65: 8558.

15. Appelros P, Stegmayr B, Terent A. Sex differences in stroke epidemiology: A systematic review. Stroke 2009; 40: 10821109. 